\title{
The Reforestation through Oil Palm Plantation in Sumatra Island
}

\author{
Jan Horas Veryady Purba \\ Department of Management \\ Sekolah Tinggi Ilmu Ekonomi Kesatuan \\ Bogor, Indonesia \\ janhorasvpurba@gmail.com
}

\begin{abstract}
The Sumatra Island is one of the important islands that has the largest contribution in the development of plantations in Indonesia. Some of the world's important commodities are produced on the Sumatra Island and deliver Indonesia into an important producing country in the world. The purpose of this study, is to examine whether the palm oil industry is becoming a "driver" of deforestation on the Sumatra Island. The method of analysis is descriptive, using secondary data from 1950 to 2016 , from Forestry Statistics, Plantation Statistics. The theory Multifunctional Agriculture is used to understand the process of reforestation. Indonesia is one of the important countries as a producer of several world commodities. Indonesia is among the top 5 in four world commodities, namely palm oil, cocoa, rubber and coffee. Oil palm, rubber and coffee have the largest share compared to other commodities on Sumatra Island. 63 percent of 11.3 million hectares of oil palm, is on the Sumatra Island. Based on Citra Landsat and other research data, shows that Sumatra oil palm plantation comes from the degraded land of 7 percent, agricultural land conversion 71 percent, degraded land forest 18 percent and protected forest 4 percent. The conversion of forests to non-forests in Sumatra is mostly $\mathbf{8 8}$ percent used for other sectors, and only 12 percent is used for oil palm plantations. In other words, oil palm plantations are not drivers of deforestation in Sumatra.
\end{abstract}

Keywords-Sumatra Island; reforestation; oil palm; degraded land

\section{INTRODUCTION}

The Sumatra Island has the largest contribution in the development of plantations in Indonesia. Some of the world's most important commodities are produced on the island of Sumatra, and deliver Indonesia into an important producing country in the global market, namely $\mathrm{CPO}$, coffee, rubber and tea. In the era of Dutch colonial development, the island of Sumatra is a designated plantation area, because it supports the type and structure of the soil, as well as climate support.

On the other side, the island of Sumatra is also one of the world's center of attention, especially by the environmentalists that associated with Sumatra elephants, as endangered animals. In the New Order era also empirically seen that logging occurs by HPH (Forest Concession Rights). Deforestation has created a negative impact on the economic, social and ecological on the island of Sumatra, due to the failure of the forest rehabilitation process. Then new issues arises and states that the rapid development of oil palm plantations throughout the province of Sumatra is blamed and considered to be a driver of deforestation in natural forests or protected forests. This ignores the historical facts of massive logging on the island of Sumatra.

However, this study does not aiming to analyze the environmental aspects, but looks at the above issues from the standpoint of economic development. Therefore, the purpose of this study, is to examine the research question: whether the rapid development of oil palm plantations is a driver of deforestation on the island of Sumatra?

\section{THEORETICAL CONCEPTS}

Theoretical concepts in this study include 3 things, ie multifunctional agriculture, deforestation and reforestation, as expalined below.

\section{A. Multifunctional Agriculture}

Multifunctional theories of agriculture include four functions namely green function, blue services, yellow services and white function [1]. The green functions consist of wildlife management, the creation of wildlife habitat and animal welfare, the maintenance of biodiversity, the improvement of nutrient recycling and the limitation of carbon sinks. Other public benefit that can be created by agriculture are blue services and contain water management, improvement of water quality, flood control, water harvesting and creation of energy. A third kind of rural cohesion and vitality, ambience and development, cultural exploiting and historical heritages, creating a regional identity and offering hunting, agro-tourism and agro-entertainment. Finally, the white function is produced by agriculture, such as food security and safety. 
In the Regulation of Plantation Indonesia (UU No. 39/2014) [2] also incorporates the multifunctional agriculture's elements, where plantations have three functions: 1) economic functioning (increasing prosperity and welfare of the people and strengthening of regional and national economic structures), 2) ecological functions (improving soil and water conservation, carbon sequestration, oxygen and buffer of protected areas) and 3) socio-cultural function, that is, the role of uniting Indonesian society.

The multifunctional agriculture function in oil palm plantations covers these three things: (1) The economic function of the palm oil industry, namely the source of foreign exchange and state revenues, the development of regional economy and the increase of farmer's income [3], and the economic benefits of the palm are also enjoyed by the EU community. CPO imports are profitable for both GDP, government revenue and EU employment opportunities [4]; (2) The socio-cultural functions of the palm oil industry play a role in rural development and poverty reduction [5], [6], [4]. In addition, the human resources involved in oil palm plantations in each region is an alliance of ethnic diversity in Indonesia. The multiethnic involvement in economic activities also means that oil palm plantations are one of the vessels for preserving the diversity of social interactions between ethnic cultural. Institutional cooperation of Perkebunan Inti Rakyat (PIR) is a blend of local cultural values with modern management is part of the social function of oil palm plantations; and (3) The ecological functions of oil palm plantations include the conservation of the carbon dioxide and oxygen cycle (photosynthesis process, which absorbs carbon dioxide from the Earth's atmosphere and generates oxygen into the Earth's atmosphere), degraded land and soil conservation land restoration, biomass increases and carbon stocks [7], [8] and even reduce greenhouse gas emissionspeatland restoration [9], [10].

The above explanation shows that the palm oil industry produces two products simultaneously, namely crude palm oil (CPO) and its derivative products, and environmental services such as the sustainability of the oxygen cycle, the sustainability of the hydrological cycle and the sustainability of the carbon dioxide cycle which is an important part of the function global ecosystem. The carbon dioxide released is absorbed by the oil palm plantations through photosynthesis and then stored in biomass form and produces oxygen for human life.

\section{B. Deforestation}

Deforestation is defined as conversion of forest land to non-forest land. This process takes place in each country especially at the beginning of its development, ie to meet the needs of land for the development of sectors and for settlements, along with the increasing population.
Therefore, deforestation is a normal phenomenon in the development process in every country in the world.

The timing of deforestation in each country depends on the period of development process taking place. On the European continent occurred since the beginning of human civilization and is estimated to end in the 13th century. While in the United States began during the $16^{\text {th }}$ century until the $19^{\text {th }}$ century. Matthew revealed the extent of deforestation in sub-tropical countries until the early 1980s had reached 653 million hectares [11].

Deforestation in other parts of the world began to occur after the end of the Second World War, in line with the development programs of each country. In the period 1990-2008 the global deforestation area reached 239 million hectares. Approximately 33 percent occur in South America, Africa 31 percent and Southeast Asia including Indonesia about 11 percent [12]. Deforestation in Indonesia has started since the colonial period. Massive deforestation has occurred since independence, especially during the New Order era in which the period of development in all sectors took place more quickly.

\section{Reforestation}

Oil palm plantations have an ecological role, such as the conservation of carbon dioxide and oxygen cycles, degraded land restoration of soil and water conservation, increased biomass and carbon stocks, reducing greenhouse gas emissions/peatland restoration. Each hectare of oil palm plantations absorbs carbon dioxide from the earth's atmosphere of 161 tons/ha and produces 18.7 tons/ha of oxygen [13]. Oil palm plantations also increase the biomass (organic matter) of the growing land with older plants [8]. Oil palm plantations on peatlands also reduce greenhouse gas emissions [9], [10], [14]. In terms of the hydrological design of hydrological indicators such as evapotranspiration, groundwater reserves, on-ground rainfall, infiltration of solum and air humidity [7], [15] between oil palm plantations and forests are relatively similar.

\section{Methodology}

The method used is empirical descriptive research, by: (1) analyzing the deforestation process and associated with the development of oil palm plantations on the island of Sumatra and (2) gathering empirical evidence relating to the economic, social and ecological aspects of the palm oil industry. To overcome this, the research traces the origin or source of land for planting oil palm in Sumatra. The data used are Forestry Statistics, Plantation Statistics, both in Sumatra and national data. In addition, various studies on the era of logging of various institutions and researchers were also used. 


\section{RESULT}

\section{A. The Contribution of Sumatra Plantation to The World}

Several important commodities on Sumatra Island are: oil palm 7.1 million ha, rubber 2.56 million ha, coconut 1.14 million ha, coffee 774,7 thousand ha, sugar cane 148.4 thousand ha and tea 15,600 ha and tobacco 5,700 ha. The total of these commodities reached 12.1 million ha [16]. From that area, it can be seen that the largest proportion is oil palm plantation (private oil palm, and smallholder) of $61 \%$, followed by rubber plantation (mostly smallholders) $22 \%$, followed by coconut $10 \%$, coffee $6 \%$, sugar cane $1 \%$ and $0.1 \%$ tea plantation (sugar cane and tea are in Java Island).

Fig. 1. Proportion of the Five Major World Countries in Palm Oil, Cocoa, Rubber and Coffee Commodities

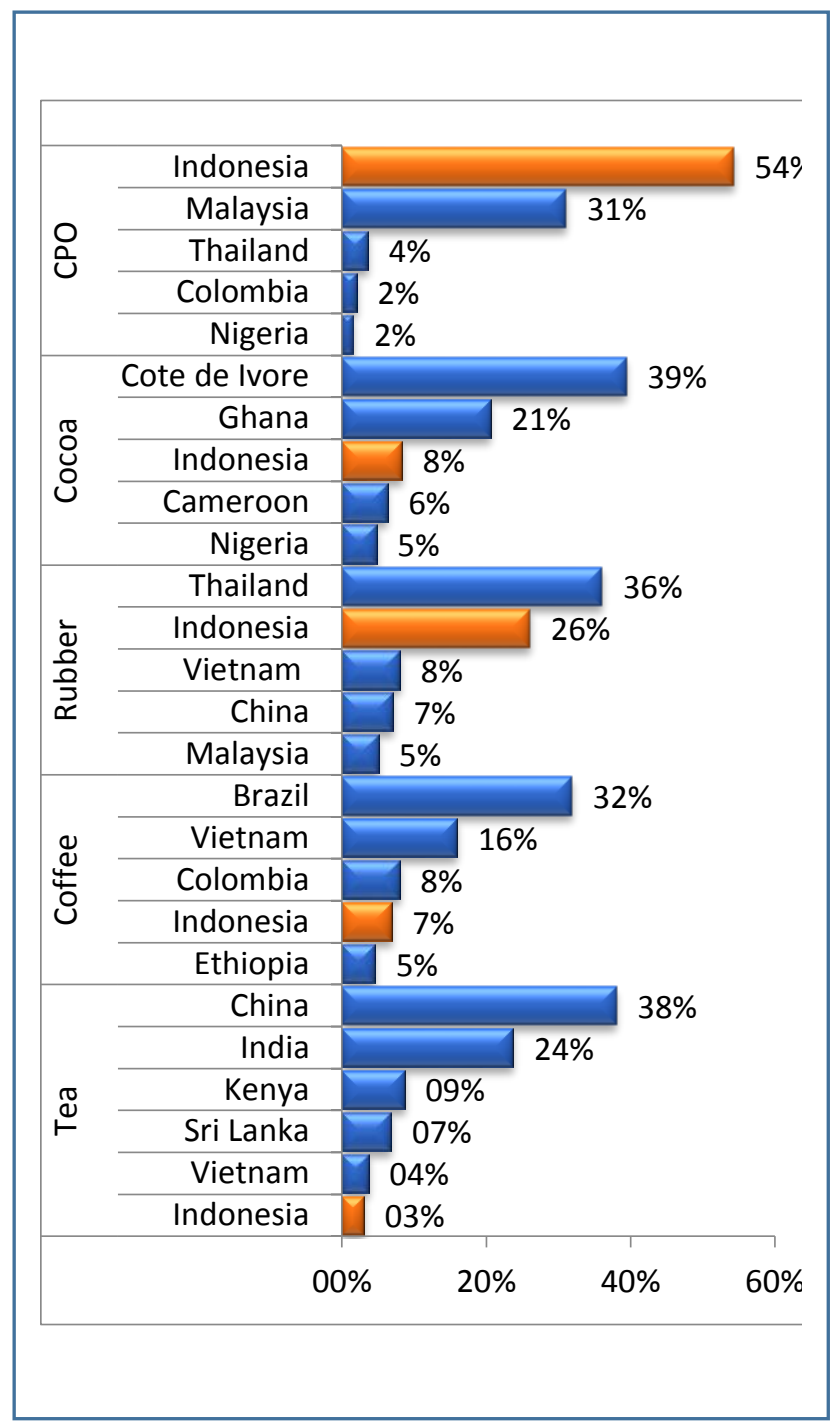

Source : United State Departement of Agriculture [22]
In global market, Indonesia is one of the important countries as a producer of several world commodities. Indonesia is among the top 5 in the world's four commodities, namely palm oil, cocoa, rubber and coffee. Indonesia's palm oil commodities are at the top in the world ( $1^{\text {st }}$ rank) with 54 percent share, and above of Malaysia, Thailand, Colombia and Nigeria.

The second largest commodity is rubber, where Indonesia in the second position (rank) after Thailand, with a share of 26 percent. In the Cocoa commodity, Indonesia ranks third, after Cote de Ivore and Ghana, with a share of 8 percent. In coffee commodity, Indonesia is ranked fourth after Brazil, Vietnam and Columbia, with a share of 7 percent. In addition to the above four commodities, Indonesia is also an important country in tea commodities, and is in sixth position, but not much different from Thailand who occupies the fifth position in the world.

Fig. 2. The Proportion of Plantations in Sumatra, Compared to the National Total

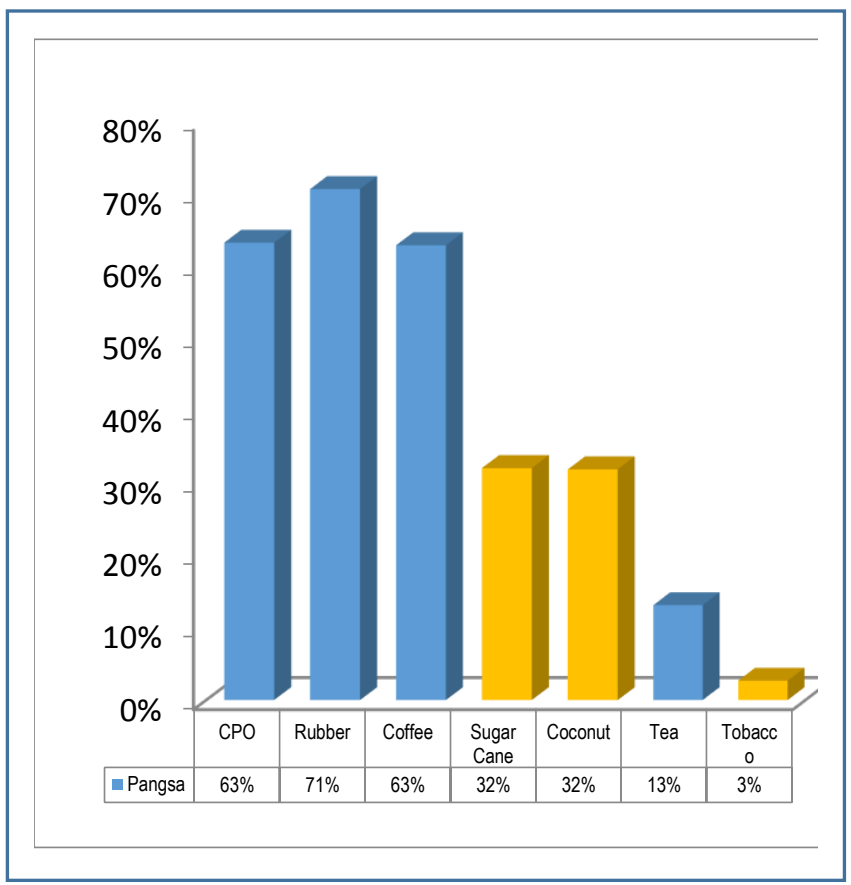

About 63 percent percent of 11.3 million hectares of palm oil, are planted in Sumatra, followed by rubber and coffee plants, with a share of 71 percent and 63 percent respectively. This shows one important thing, where the island of Sumatra has included meritorious and active role in world market. Historically the past shows that Indonesia once occupied the top position in rubber commodities, but due to mismanagement, Indonesia fell drastically and began to rise again in recent years. Therefore, the above comparison is also intended for palm oil not to repeat the same history, but still able to play a role as a leader in the global market. 


\section{B. Logging and Deforestation Era}

Almost all countries in the world are doing the logging process for development purposes. Forest utilization, therefore, is a normal phenomenon. In line with the increasing population growth, and the need for land for development and settlement, conversion of forests into non-forests is to some extent a rational choice. These logging and conversion periods vary by country, depending on the initial period of construction.

Matthew's study reveals that in the period 1600-1980 the conversion of forests to non-forests reached 701 million hectares worldwide and about 653 million hectares or 93 percent occurred in sub-tropical regions, especially in Europe and North America [11]. Then, according to the European Commission study, the area of forest conversion into non-forest world during 1990-2008 reached 239 million hectares where about 64 percent occurred in South America and Africa [4].

As the phenomenon in each country, the same thing happened in Indonesia. The New Order which was the beginning of development in Indonesia, logging and forest conversion occurred massively. How history of logging and conversion in Indonesia including in Sumatra can be traced to many publications such as Hidayat [17a.b], Kartodihardjo and Supriono [18]; Forest Watch Indonesia [19]; Gunarso [20].

Until 1950, non-forest areas on the island of Sumatra had reached 9.8 million ha. During the period 1950-1985 forest conversion increased by 14 million hectares, and the total non-forest area reached 23.8 million hectares. Then in 1985-2000 the area of forest conversion accumulatively reached 31.6 million hectares. While in the period 2000-2013 the accumulation of forest conversion reached 34.2 million hectares. Although logging and conversion of forests into non-forests occurs, Sumatra is still relatively good. If in Europe and North America during the logging period spent almost all primary forest including its inhabitants (biodiversity), Indonesia including Sumatra is still better. On the island of Sumatra for example, forest area is still about 12.8 million hectares or about 28 percent of the land area of Sumatra Island. The forest consists of protected/conservation forests, production forest, limited production forest, and production forest can be converted. The forest area is still above the minimum forest minimum requirements determined by Law no. 41/1999 Forestry and Law no. 26/2007 abot Space Low (RTRW) namely minimum 30 percent of land. The conversion of non-logged forest to non-forest prior to 2000 was partly for transmigration areas, settlement needs, but most were left degraded land or as land subsidized land during the New Order period, often burning [18].
The logging and forest conversion histories are presented below.

Fig. 3. Oil Palm Plantation in Land Use Change in Sumatra Island

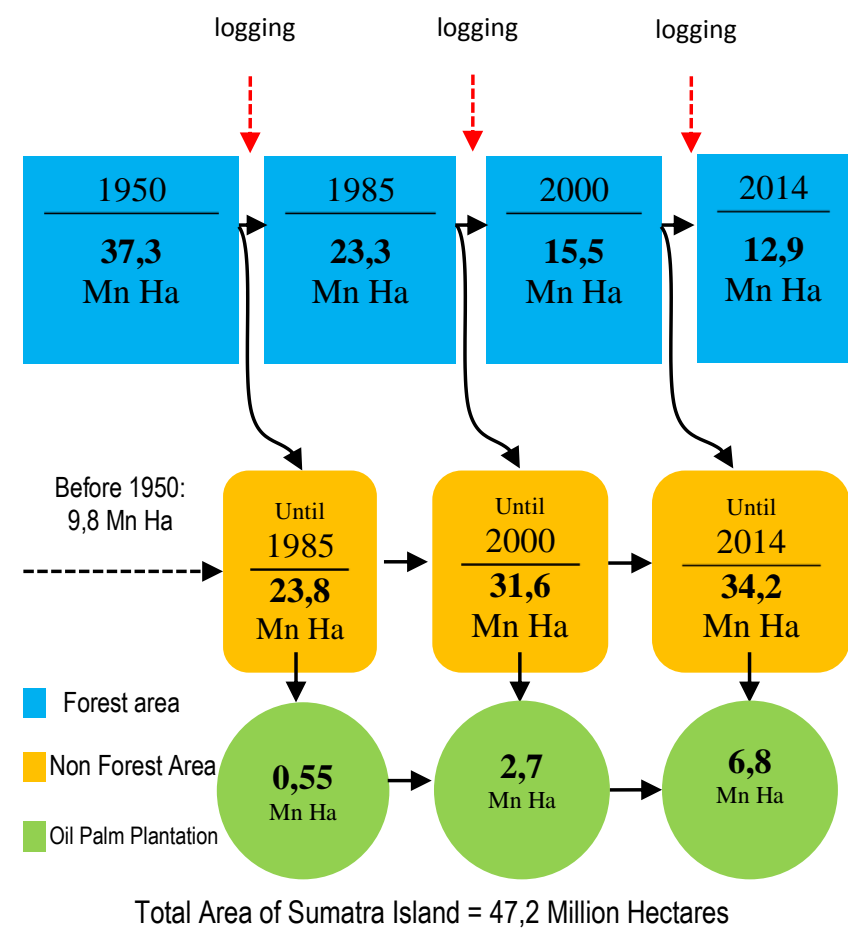

Source: Oil Palm Statistics [16]; PASPI, 2017 [21]

\section{DISCUSSION}

The interesting thing about the history of logging and forest conversion in Sumatra is the new oil palm plantation in Sumatra in the future. Until 1985, the area of oil palm plantations in Sumatra only reached 550 thousand hectares. While the forest conversion that has occurred is 23.8 million hectares. Then the area of oil palm plantations until the year 2000 only reached about 2.7 million hectares whereas until 2000 the area of forest conversion on the island of Sumatra has reached 31.6 million hectares. Up to 2014 , the area of oil palm plantation in Sumatra has only reached 6.8 million hectares or while the total area of forest conversion into non-forest on the island of Sumatra has reached 34.2 million hectares. Based on the data it is clear that forest conversion to non-forest in Sumatra is mostly 88 percent used for other sectors use, and only 19.6 percent is used for oil palm plantations. In other words, oil palm plantations are not drivers and major users of forest conversion to non-forest (deforestation) on the island of Sumatra

By tracing the origins of oil palm plantations in Indonesia, concluding the expansion of oil palm plantations is not a driver of deforestation in Indonesia. 
Based on Citra Land Set [20] and other research data, the amount of palm oil from deforestation and reforestation, shows that Sumatra oil palm plantation comes from degragaded land of 7 percent, agricultural land conversion 71 percent, degraded land forest 18 percent and undisturbed forest 4 percent. Deforestation (from undisturbed production forest conversion) is only about 4 percent, while from reforestation (from conversion of agricultural land, degragaded land, degraded forest) by 96 percent. If the production forest is disrupted, it is also categorized as deforestation, then the oil palm plantation of Sumatra originating from deforestation is 22 percent and the rest of which is 78 percent in the form of reforestation. So that in net (reforestation - deforestation) expansion of oil palm plantation in Sumatra is reforestation (increasing area carbon stock). Thus oil palm plantations in Sumatra other than not the driver of deforestation are also a reforestation. The accusation that oil palm expansion is a major driver of deforestation is not supported by data. Oil palm plantation actually regreening the ecology and economy of the area damaged by logging in the past. For people who are in Sumatra Island or those who have visited Sumatra before 2000, can feel and experience how sad the economic condition of the people on the island of Sumatra. Prior to 2000 especially in the period 1960-1985, logging of Sumatra was very intensive by the owner of HPH which generally came from outside of Sumatra.

Millions of tons of $\log$ each year out of Sumatra either directly exported or used in Java. Uncontrolled logging activities at the time, spent about 18.5 million hectares of forest and gave birth to wooden kings known before the year 2000. Logging activities are still running after the year 2000 although not as intensive as the previous period. Until 2014, the conversion of ex HPH into non-forest land has reached 33.6 million hectares. The result of logging by HPH is all taken out from Sumatra to other areas, especially Java Island. Sumatra island during the New Order period suffered from capital drain and no logging returns (re-investment) to the island of Sumatra. As a result, former HPH in Sumatra became an underdeveloped, poor, dry, and dead area. All that remains is the ruins of logging barracks, logging roads, ex HPHs that turn into underbrush. In regional economics term is referred to as "ghost town". And to cover the trace of illegal logging, the New Order government then converted it into non-forest area in the form of degragaded land and partly for transmigration areas.

After the New Order Era collapsed and switched to the Reformation Era in 2000, saw the extent of degragaded land of former logging concessionaires proactive local government utilize the degragaded former $\mathrm{HPH}$ land for development sectors including the plantation sector. One of the fastest growing sectors utilizing the degragaded land is oil palm plantations. World palm oil prices that began to benefit at the beginning of the reform era to make palm oil investment attractive to the investors. This is reflected in the increase in the area of Sumatra's oil palm plantation from about 2.7 million hectares in 2000 to 6.8 million hectares in 2014 , both public palm oil, private palm oil and palm oil.

In present condition, the oil palm plantations have been able to utilize about 13 percent of the approximately 27 million hectares of degragaded land of ex HPH in Sumatra. However, in contrast to the logging periods that cut down the palm oil plantation trees, they planted trees. If logging depletes resources and brings out Sumatra, palm oil plantation actually incorporates resources in the form of new investments to Sumatra. The inclusion of palm oil investments adds "fresh blood" to the economy of Sumatra so that it evolutionarily drives the economic wheels of Sumatra. The expansion of oil palm plantation attracted the development of other wider and more rapid economic sectors in Sumatra and created a multicultural, economic, and ecological benefit for Sumatra. Not only are the economies flourishing, the degragaded lands are transformed into green oil palm plantation. Carbon dioxide released during logging is reabsorbed by oil palm plantations and then converted to oxygen, palm oil and biomass. Forests as the pulmonary ecosystems lost by logging, are now being replaced by better new lungs of oil palm plantations. Oil palm plantation have been and are re-"greening" Sumatra's economic and ecosystems. The greening process is still ongoing in the future. Being, the cities in the province and the district are growing rapidly. The sub-district townships that were formerly just like kampongs turned into District Cities. Logging barracks that once slum turned into new economic growth centers in the interior of Sumatra. The center of a new growing economic growth based on oil palm plantations. Palm plantation together with other economic sectors based on renewable resources, re-greening Sumatra Island post logging. Greening socially, greening economically and greening ecologically.

\section{CONCLUSION}

The conversion of forests to non-forests in Sumatra is mostly 88 percent used for other sectors, and only 12 percent is used for oil palm plantations. In other words, oil palm plantations are not drivers, and major users of forest conversion to non-forest (deforestation) on the island of Sumatra. The island of Sumatra during the postlogging era and suffered from draining of resources and logging results no re-investment to the island of Sumatra. As a result, the remaining ex-HPH in Sumatra is the ruins of logging barracks, logging roads, former HPHs that turn into undisturbed shrubs, underdeveloped, poor, dry, and dead areas, which in regional economic terms are referred to as ghost towns.

The presence of oil palm plantations in Sumatra actually re-green the social, economic and ecological areas damaged by logging in the past. The inclusion of 
palm oil investments adds "fresh blood" to the economy of Sumatra so that it evolutionarily drives the economic wheel of Sumatra. The expansion of oil palm plantations, attracted the development of other sectors of the wider economy and rapidly created a multidiscipline of social, economic, and ecological benefits and spurred new economic growth centers in Sumatra.

By tracing the origins of oil palm plantations in Sumatra Island, this research find two important things: (a) the oil palm plantation in Sumatra only 4 percent comes from deforestation (from undisturbed production forest conversion) and 96 percent from conversion of agricultural land, degragaded land, and degraded forest), (b) during the period of 1950-2013, the accumulation of forest conversion reached 34.2 million hectares, and oil palm plantations originating from protected forests are 0.27 million ha. It can be concluded that the expansion of oil palm plantations is not a driver of deforestation in Sumatra. From the perspective of reforestation, as much as 78 percent of oil palm plantations in Sumatra can be categorized as reforestation and also have contributed to the improvement of environmental quality in Sumatra.

\section{Acknowledgment}

I would like to express my special thanks of gratitude to Sekolah Tinggi Ilmu Ekonomi Kesatuan (STIE Kesatuan) that gave me the opportunity to do this research. Secondly i would also like to thank PASPI (Palm Oil Agribusiness Strategic Policy Institute), Bogor and all Staffs, that helped me a lot in finalizing this reseach within the limited time frame.

\section{References}

[1] Aldington, T.J. 1998, "Multifunctional Agriculture: a Brief Review from Developed and Developing Country Perspectives". FAO Agriculture Department, Internal Document.2

[2] Undang-Undang No. 39 Tahun 2014 Tentang Perkebunan

[3] PASPI, 2014 : Industri Minyak Sawit Indonesia Berkelanjutan. Peranan Industri Minyak Kelapa Sawit dalam Pertumbuhan Ekonomi, Pembanguunan Pedesaan, Pengurangan Kemiskinan dan Pelestarian Ling-kungan. Palm Oil Agribusiness Strategic Policy Institute. Bogor.

[4] Europe Economics. 2014. The Economic Impact Of Palm Oil Imports In The EU. Europe economics, chancery house, 53-64 chancery lane. London WC2A IQU.
[5] Susila, W. R. 2004. Contribution of Palm Oil Industry to Economic Growth and Poverty Allevation in Indonesia. Jurnal LITBANG Pertanian 23(3).

[6] World Growth, 2009: Conversion The Immutable Link Between Forestry and Development, Arlington VA.

[7] Henson I. 1999. Comparative Ecophysiology of Palm Oil and Tropical Rainforest. Oil Palm and Environment A Malaysian Perspective. Malaysian Oil Palm Brower Council. Kuala Lumpur.

[8] Chan, K. W. 2002: Oil Palm Carbon Sequestration and Carbon Accounting: Our Global Strength. MPOA.

[9] Murayama, S. and Baker, Z. A. 1996. Decomposition of Tropical Peat Soils. Decomposition Kinetic of Organic Matter of Peat Soils. Japan Agricultural Research. Quarterly. 30: 145-151.

[10] Melling, L. Goh. K.J. and R. Hatanto.2007. Comparison Study Between GHG Fluxes from Forest and Oil Palm Plantation on Tropical Peat Land of Serawah Malaysia. International on Oil Palm and Environ-ment. Bali. Indonesia.

[11] Matthew, E. 1983. Global Vegetation and Land Use: New High Resolution Data Based for Climate Study. Journal of Climate and Applied Meteorology 22: (474-487)

[12] European Commission. 2013. The Impact of EU Consumption on Deforestation: Identification of Critical Areas Where Commmunity Policies and Legislation Could be Review.

[13] Fairhurst. T. and R. Hardter, 2004: Oil Palm: Management for Large and Sustainable Yields. Oxford Graphic Printers, Pte Ltd.

[14] Sabiham, S. 2013. Sawit dan Lahan Gambut dalam Pembangunan Kebun Kelapa Sawit di Indonesia. Himpunan Gambut Indonesia.

[15] Harahap, I. Y, Y Pangaribuan, H. H Siregar, E Listia. 2005: Lingkungan Fisik Perke-bunan Kelapa Sawit. PPKS. Medan

[16] Kementerian Pertanian RI. 2016. Statistik Perkebunan Kelapa Sawit Indonesia 2013-2015. Kementerian Pertanian RI. Jakarta

[17a] Hidayat. H. 2008. Politik Lingkungan : Pengelolaan Hutan Masa Orde Baru dan Reformasi. Yayasan Obor Indonesia.

[17b] Hidayat,. H. 2015. Forest Resources Management in Indonesia 1968-2004 : A Political Ecology Approach. Springers.

[18] Kartodihardjo, H dan A. Supriono. 2000. Dampak Pembangunan Sektoral Terhadap Konversi dan Degradasi Hutan Alam; Kasus Pembangunan HTI dan Perkebunan di Indonesia. Center for International Forestry Research. Bogor

[19] Forest Watch Indonesia. 2001. Keadaan Hutan Indonesia. Bogor Indonesia

[20] Gunarso, P, M. E. Hartoyo, Y. Nugroho, N.I. Ristiana, R. S. Maharani. 2012: Analisis Penutupan Lahan dan Perubahannya Menjadi Kebun Kelapa Sawit di Indonesia Tahun 1990-2010.

[21] PASPI, 2017 : Mithos versus Fakta. Industri Minyak Sawit Indonesia. Palm Oil Agribusiness Strategic Policy Institute. Bogor.

[22] United State Departement of Agriculture, 2016. Index Mundi. 